\title{
The role of interregional relationships in research talent development
}

\author{
I.V. Naumov ${ }^{1,2,3} \bowtie$, A.Z. Barybina ${ }^{1}$ \\ ${ }^{1}$ Institute of Economics, Ural Branch of the Russian Academy of Sciences, Ekaterinburg, Russia; e-mail: Ilia_naumov@list.ru \\ ${ }^{2}$ Ural State Mining University, Ekaterinburg, Russia \\ ${ }^{3}$ Ural State Economic University, Ekaterinburg, Russia
}

\begin{abstract}
The relevance of research. Workforce quality is paramount to the development of innovative economy and socio-economic development of territorial systems. Not all regions, however, are able to train sufficient R\&D personnel to meet the needs of their innovative economies. The lack of research talent can be compensated by establishing cooperative relationships with other territorial systems. Therefore, it is important to study the existing interregional interconnections in the development of research talent and to identify the key priorities in this sphere. The aim of the study is to demonstrate the relationship between the indicators of development of research talent in different regions and their innovative activity. Data and Methods. The study uses spatial econometric modeling tools and methods for calculating global and local spatial autocorrelation indices of Moran P. and their dispersion diagrams. The spatial autocorrelation was calculated by using a standardized matrix of distances along the roads between the regional administrative centers. As a result of the analysis, a close relationship was found between the indicators of development of research talent in Russian regions and their innovative activity. The constructed regression model based on spatial data lead us to the conclusion that efficient innovative development requires a pool of STEM talent in the regions, which means that it is necessary to provide sufficient opportunities for training and education in this sphere. Conclusions. The study of the interconnections between the regions using the improved method of spatial autocorrelation of P. Moran revealed a cluster of closely interconnected regions (Moscow - St. Petersburg - Moscow region - Nizhny Novgorod region Ryazan region - Ivanovo region - Tver region - Kostroma region - Tula region) and three potential clusters: 'Volga', 'Ural', and 'Siberia'.
\end{abstract}

\section{KEYWORDS}

regional system, research talent, innovative economy, inter-regional relations, spatial autocorrelation, spatial autoregressive analysis

\section{FOR CITATION}

Naumov, I.V., \& Barybina, A.Z. (2020). The role of interregional relationships in research talent development.

R-economy, 6(1), 14-27. doi: $10.15826 /$ recon.2020.6.1.002

\section{Исследование межрегиональных связей в процессе развития научных кадров инновационной экономики}

\author{
И.В. Наумов ${ }^{1,2,3} \bowtie$, А.З. Барыбина ${ }^{1}$ \\ ${ }^{1}$ Институт экономики Уральского отделения Российской академии наук, Екатеринбург, Россия; \\ e-mail: Ilia_naumov@list.ru \\ 2 Уральский государственный горный университет, Екатеринбург, Россия \\ ${ }^{3}$ Уральский государственный экономический университет, Екатеринбург, Россия
}

\section{АННОТАЦИЯ}

Актуальность исследования. Существующая инфраструктура научно-технического комплекса не в состоянии обеспечить условия для формирования и развития инновационной экономики без наличия необходимого научно-технического кадрового потенциала, даже если рассматривается территориальная система, обеспеченная финансовыми ресурсами. В связи с этим важно изучить существующие межрегиональные взаимосвязи в развитии кадрового потенциала инновационной экономики и определить приоритетные направления их развития. Целью исследования является поиск и подтверждение взаимосвязи между показателями развития научных кадров в регионах и показателем их инновационной активности. Данные и методы. Исследование межрегиональных связей основано на использовании инструментов пространственного эконометрического моделирования, а также методов расчета глобальных и локаль(c) Naumov, I.V., Barybina, A.Z., 2020

\section{КЛЮЧЕВЫЕ СЛОВА}

региональная система, научно-кадровый потенциал, инновационная экономика, межрегиональные связи, пространственная автокорреляция, пространственный авторегрессионный анализ 
ных пространственных индексов автокорреляции Морана П. и диаграмм дисперсии. Пространственная автокорреляция рассчитывалась с использованием стандартизированной матрицы расстояний вдоль дорог между областными административными центрами. В результате анализа была обнаружена тесная связь между показателями развития научных кадров в регионах и инновационной активности. Построенная регрессионная модель на основе пространственных данных позволила сделать вывод о том, что формирование инновационной экономики требует развития кадрового научного потенциала, воспроизводства персонала, занимающегося исследованиями и разработками. В ходе исследования мы пришли к выводу, что для инновационного развития регионов необходимо воспроизводить научные кадры в области фундаментальных и прикладных исследований, а также инженерно-технические кадры. Выводы. Изучение взаимосвязей между регионами с использованием усовершенствованного метода пространственной автокорреляции П. Морана позволило установить кластер тесно взаимосвязанных регионов (Москва - Санкт-Петербург - Московская область - Нижегородская область - Рязанская область - Ивановская область - Тверь область - Костромская область - Тульская область) и три потенциальных кластера: «Волга», «Урал», «Сибирь».

\section{ДЛЯ ЦИТИРОВАНИЯ}

Naumov, I.V., \& Barybina, A.Z. (2020). The role of interregional relationships in research talent development.

R-economy, 6(1), 14-27.

doi: $10.15826 /$ recon.2020.6.1.002

\section{Introduction}

Workforce quality is paramount to the development of innovative economy and socio-economic development of territorial systems along with other factors such as financial resources; institutional environment; production, transport, engineering and research infrastructure. Highly qualified researchers and engineers are necessary to generate innovative ideas and create the necessary conditions for their successful implementation, which, in its turn, also relies on constant engineering support and technical supervision.

The key role of research talent in the formation and development of an innovative economy in Russia has been confirmed by our previous studies $[1 ; 2]$. In these works, we have identified the active reduction in the number of research personnel in the field of natural and technical sciences as well as the decrease in the number of engineering personnel. These negative trends in the reproduction of human resources in $R \& D$ resulted from the structural shift in the state priorities of funding applied research. Since 2004, basic science in Russia has been funded on a residual basis.

Since 2009, the number of patents for inventions granted to innovative enterprises and research organizations has been reduced. The patent structure has come to be dominated by utility model patents rather than inventions as it used to be. This has led to the situation where Russian innovative enterprises and research organizations are focused not on the creation of fundamentally new technologies, technical innovations, but on the modernization and im- provement of the existing ones. A study of the dynamics of scientific and technological potential in Russia, intellectual resources, research of the processes of their reproduction has led us to the conclusion that the accumulated scientific potential is not used to create advanced technologies and the current trends can lead to its further deterioration in the future.

Formation and development of an innovative economy can be impeded by the lack of qualified scientific, technical and engineering personnel. Figure 1 shows that in Russia there are few innovation-oriented regions with sufficient human resources in R\&D. This figure shows that the leading regions in this respect are the city of St. Petersburg, the city of Moscow, Moscow region, Nizhny Novgorod region, Sverdlovsk region, Chelyabinsk region, Tyumen region, Samara region, Rostov region, Perm region, Krasnodar region, the Republic of Tatarstan and the Republic of Bashkortostan. Some regions have sufficient scientific personnel, but do not differ in high rates of innovation activity (Novosibirsk Region, Voronezh Region, Tomsk Region, Kaluga Region, Leningrad Region, Yaroslavl Region and Krasnoyarsk Krai). Despite the high rates of innovation activity, some regions do not have enough specialists to generate new ideas and technologies (Belgorod Region, Arkhangelsk Region, Tula Region, Lipetsk Region, Khabarovsk Territory, the Republic of Mordovia and Udmurtia).

Obviously, not all regions have the scientific and technical potential, innovative infrastructure, R\&D personnel necessary to develop an innovative economy, which complicates the process of in- 
novative development of these territories but does not impede its implementation. In modern conditions of economic development and the strengthening of cooperative relationships between territorial systems, the generation and implementation of technological innovations does not require the construction of new research institutions and the creation of a powerful innovation infrastructure in each region. It is enough to form and develop close relationships with scientific and technological complexes, objects of innovative infrastructure that operate in other territorial systems and have powerful human resources for the generation of new technologies. Interregional cooperation of the territories in the sphere of research talent development will allow them to compensate for the lack of innovation infrastructure in the territory and create conditions for the development of an innovative economy. Interregional cooperation between the territories is necessary for the exchange of technological experience and implementation of technologies, training of $\mathrm{R} \& \mathrm{D}$ personnel, involvement of unique specialists for the development of technical and technological innovations and their implementation, for coo- peration in servicing innovative production technologies and so on.

The study of the interregional connections in the development of research talent and the identification of priorities for its development is particularly relevant in the light of the processes described above. The main objectives of this study are to analyze the availability of research talent necessary for the formation of an innovative economy and to evaluate the relationships between regions in terms of developing human resources for an innovative economy.

\section{Literature review}

The most significant theory for understanding the economic essence of human resources in $\mathrm{R} \& \mathrm{D}$, in our opinion, is the human capital theory of T. Schulz and G. Becker [3], who saw human capital as a component of innovative production: 'knowledge, skills, practical experience, inspired by intellectual activity, are a form of realization of a person's intellectual, moral and culturally oriented abilities to create new, previously unknown knowledge, providing intellectual rent and various advantages over competitors' [4, p. 332].

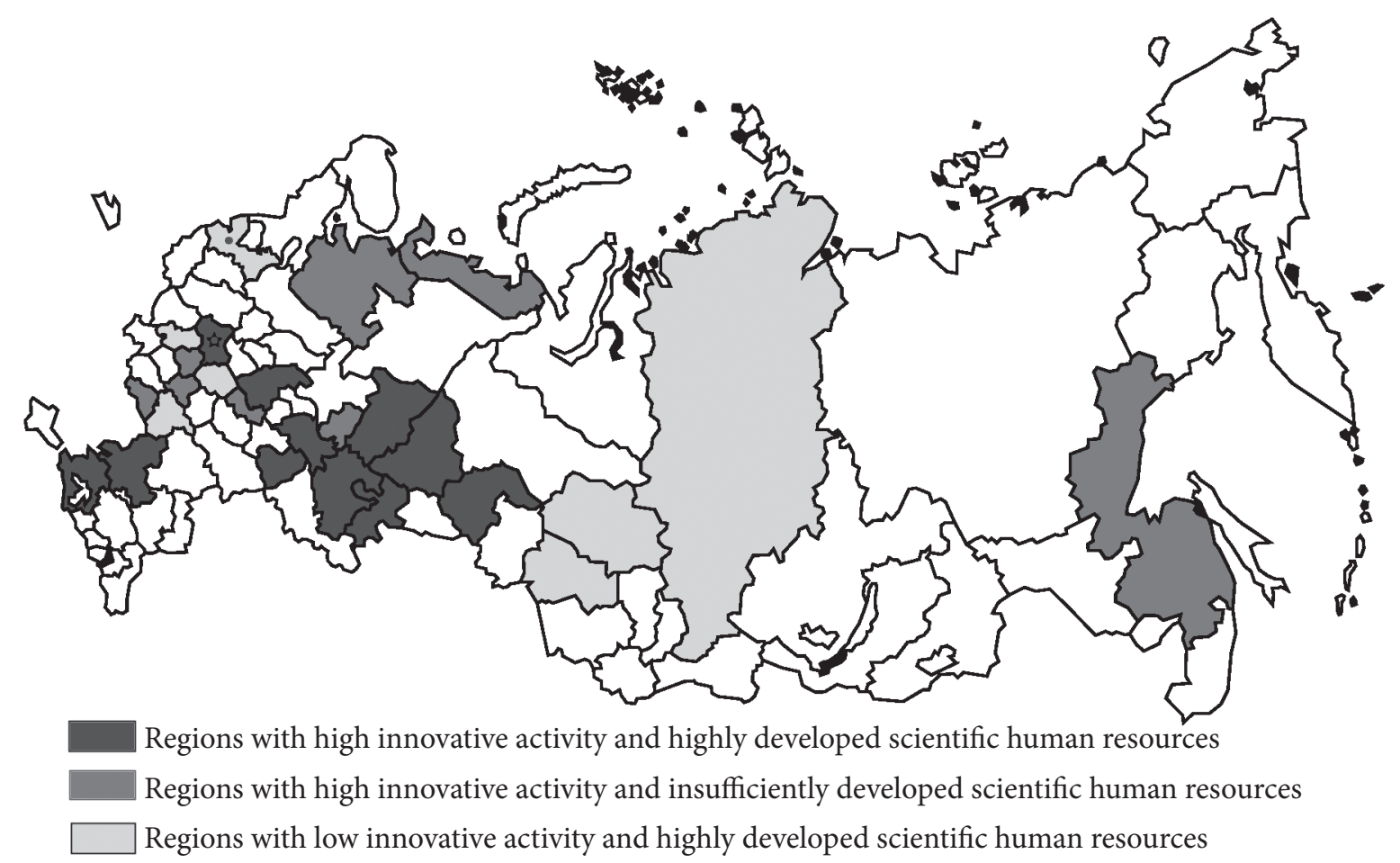

Figure 1. Spatial differentiation of regions according to the level of innovative activity and research talent ${ }^{1}$ Source: the authors' calculations are based on the data from 'Regions of Russia. Socio-economic indicators'. 2018, statistical data. Moscow: Rosstat; 2018, pp. 1162, 902-907, 954-955

${ }^{1}$ In this study, we consider a value that exceeds the average level in terms of the volume of produced and shipped innovative goods, works, services in million rubles as a high level of innovative activity in the region; a value that exceeds the average level in terms of the number of R\&D personnel, as a high level of development of research talent. 
Therefore, intellectual activity is the component that distinguishes creative work abilities from performing work abilities, human capital from simple labor, and determines the conditions and nature of the process of 'capitalization' of intellectual labor abilities.

There is no universally accepted definition of 'research talent'. In the National Human Development Report of the Russian Federation: 'Demographic Challenges of Russia', there are outlined three methodological approaches:

- philosophical approach [5, p. 1472], which interprets research talent as 'an abstract category, deprived of the ability to change over time, but having initial creative power' (Thomas Aquinas, A.A. Ukhtomsky, P.A. Florensky);

- psychological and pedagogical approach [6, p. 25], which defines research talent as 'the ability to learn, intellectual abilities (competence, initiative, creativity, self-regulation, uniqueness of mindset)' (D.B. Epiphany, L.S. Vygotsky, A.I. Kochetov, A.I. Subetto);

- socio-economic approach $[4 ; 7$, p. 228; 8; 9], which links the complex characteristics of the development of intellectual, creative capabilities of an individual and the country's resources with the functioning of the fields of education and science and the acceleration of scientific and technological progress (V.K. Levashov, B.G. Kleiner, Y.P. Lezhnina, R.E. Leshchiner, A.I. Tatarkin, A.F. Martynov).

The essence of the research talent may be considered in relation to the two key concepts 'intelligence' and 'potential', the latter being understood as 'funds, stocks available and those that can be mobilized, used to achieve a specific goal, implement a plan, solve a problem' [10, p. 281]. Intelligence is an individual property that determines the possibility of mental activity [11, p. 71]. In modern studies, intelligence is often associated with the philosophical concept of noosphere [12, p. 25]. For R\&D personnel to fulfill their functions, such elements of intelligence as knowledge and mental abilities are needed. In other words, their function is to solve practical or theoretical problems with the required efficiency. Researchers and engineers possess specific competencies - 'a strategic resource that predetermines the social and economic life of the country for decades' [13, pp. 76-96]. Certain efforts on the part of social institutions such as the family and the state contribute not only to the formation of highly qualified workforce, but also to the realization of their intellectual potential in production, creation of cultural values, social management, upbringing, etc. Within this approach, intelligence is considered as a socio-economic category [14].

The role of research talent in the formation and development of an innovative economy can be evaluated differently. Some studies consider the research talent as a combination of material, labour, financial, natural and information resources of social production and, therefore, as a reflection of the national economy's ability to use knowledge technologically and commercially for socio-economic development $[15$, p. $18 ; 16$, p. 20]. Another approach was proposed by L.S. Blyakhman, F.L. Merson, and E.M. Peat [17, p. 56], who put the main emphasis on the results of innovation, in particular financial gains from the sale of intellectual goods in foreign markets. Some studies use a resource-effective approach ([18, p. 45]), in which case the analysis and assessment of intellectual potential is based on an integral indicator combining the results of intellectual activity and resources. Within this approach, the main focus is made on the national economy's ability to benefit from the intellectual capabilities of the research staff $[19$, p. 20]. The problem of the role that research talent plays in building an innovative economy is discussed in a number of other studies [20-32]).

\section{Methodology}

Our spatial non-linear regression analysis uses the least-squares method and confirms the close relationship between the research talent in the regions and their level of innovation ${ }^{2}$ :

$$
V=\mathrm{e}^{10.4} P^{0.009} \text {, }
$$

where $V$ is the volume of produced innovative goods and services in 2017, $\mathrm{mln}$ rubles; $P$ is the number of R\&D personnel in 2017, people.

As a result of the analysis of 84 Russian regions in 2017, we constructed a statistically significant non-linear regression model. The correlation coefficient $(R=0.8)$ and determination $(R 2=0.63)$ indicated a close correlation between the variables; the significance of the determination coefficient $(F<0.05)$ confirmed the statistical significance of this indicator and the sufficiency of statistical data for building the model. P-values of all regression coefficients confirmed the de-

${ }^{2}$ To assess the level of development of research talent, we used an indicator of the number of R\&D personnel; to assess innovation in the region, we analyzed the volume of innovative products produced. 
pendence of the volume of produced innovative goods, works, services on the number of $R \& D$ personnel (see Table 1). All Gauss-Markov conditions for the constructed regression model are satisfied. The mathematical expectation of residuals in the model is close to zero, multicollinearity between factor variables and autocorrelation between residuals is absent. The accuracy of the constructed regression model was confirmed graphically. The simulated values of the volume of output of innovative goods and services in the regions copy real values.

The study of the relationship between territorial systems today is carried out by using three theoretical and methodological approaches:

- spatial econometrics (spatial autocorrelation and autoregression);

- spatial agent-based modeling;

- simulation of socio-economic processes in space using interindustry balance.

Despite the significant substantive difference between these methodological approaches, they have one thing in common, that is, the correlation and regression functional relationships between the given objects in space. Therefore, the formation of a spatial simulation model is impossible without an idea of the existing functional relationships between regional systems, without regression dependencies of the processes under study on the action of external and internal factors. These relationships are revealed in the course of spatial autocorrelation and autoregressive analysis. The functional regression dependences revealed through spatial econometrics create the foundation for agent-based modeling of the in- teraction of specific objects in space. Spatial autocorrelation and autoregressive analysis allow us to identify clusters of interconnected territories, which, when implementing an agent-based approach, can help us solve the most important problem of research and modeling the processes of moving agents between territorial systems. Our study showed that the methodological approach involving the use of tools such as spatial autocorrelation and autoregression is the basic approach in studying the interconnections between territorial systems of various levels in socio-economic processes. The basics of spatial autocorrelation analysis were formed by P. Moran [33], W. Alonso [34], L. Anselin [35], R. Geary [36], A. Getis and J.K. Ord [37]. In this article, the study of interregional relationships in the development of research talent will be based on the use of spatial econometrics tools according to the algorithm tested in our earlier work (Figure 2).

The main goal at the initial stage of our study was to study the structure and the key elements constituting research talent. To this end, we propose the use of correlation and multiple linear / non-linear regression analysis using the least squares method with an assessment of the statistical reliability of the constructed model. Regression analysis will allow us to establish the core elements that contribute to the development of an innovative economy in regional systems, which means that these elements should be prioritized and their reproduction will require active interregional cooperation. The study of interregional interconnections is to be carried out by using a modified methodology for calculating global and

Table 1

Results of non-linear spatial regression analysis of the dependence of the volume of produced innovative goods, works, services on the number of $R \& D$ personnel

\begin{tabular}{|c|c|c|c|c|c|}
\hline \multicolumn{2}{|l|}{ Regression statistics } & & & & \\
\hline Correlation coefficient (R) & 0.80 & & & & \\
\hline Coefficient of determination & 0.63 & & & & \\
\hline Standard error & 18.1 & & & & \\
\hline \multicolumn{6}{|l|}{ Analysis of variance } \\
\hline & $\mathrm{d} f$ & SS & $M S$ & $F$ & $F$ value \\
\hline Regression & 1 & 44737 & 44737 & 136 & $7.08 \mathrm{E}-19$ \\
\hline Residual & 79 & 25932 & 328 & & \\
\hline Total & 80 & 70669 & & & \\
\hline
\end{tabular}

\begin{tabular}{|c|c|c|c|c|c|c|}
\hline Regression coefficients & & Standard error & $t$ - statistics & $P$-value & Lower $95 \%$ & Upper 95\% \\
\hline constant & 10.4 & 2.1 & 4.9 & 4.6E-06 & 6.2 & 14.6 \\
\hline$P$ & 0.0009 & 7.3E-05 & 11.7 & $7.1 \mathrm{E}-19$ & 0.0007 & 0.001 \\
\hline
\end{tabular}

Source: the authors' calculations based on the data from 'Regions of Russia. Socio-economic indicators'. 2018, statistical data. Moscow: Rosstat; 2018, pp. 1162, 902-907, 954-955. 
local spatial autocorrelation indices P. Moran, diagrams of their dispersion. This analysis will allow us to do the following:

- establish the relationship between regional systems in terms of the development of elements of research talent;

- determine the direction of this connection (direct or reverse);

- establish the main centers of localization of research talent and their influence zones;

- identify the territories that lack human resources and are in need of close interactions with other regions for the development of an innovative economy.

The P. Moran dispersion diagram will help us identify spatial priorities for the development of research talent and closely related regions which receive a strong impetus in the development of human resources. The algorithm for the implementation of spatial autocorrelation of regions in terms of the development of elements of research talent is presented in Figure 2 above. The spatial autocorrelation to be carried out by using a standardized matrix of distances along the roads between the administrative centers of Russian regions. Our studies have shown that the use of other types of standardized distance matrices in the calculation of Moran indices does not lead to radically different results from the technique we use. According to the traditional technique of
Patrick Moran, interterritorial relationships are estimated by using spatial adjacencies (using a matrix of standardized distances along adjacent borders). The determination of the neighborhood of territories in this methodology is based on the presence of common borders. The weights between features form a matrix of spatial weights. It reflects the intensity of geographical relations between neighboring objects. The type of distance matrices does not seriously affect the search for interconnections between territorial systems. In all cases, the results we obtain from the P. Moran dispersion diagram have a similar form. When using various distance measurement systems, the values of the global and local Moran indices differ, which are used to assess the tightness of the relationship. The calculation of these indicators is proposed to be carried out according to the traditional method of spatial autocorrelation of Moran:

$$
\begin{gathered}
I_{G}=\frac{N}{\sum_{i} \sum_{j} W_{i j}} \cdot \frac{\sum_{i} \sum_{j} W_{i j}\left(x_{i}-\mu\right)\left(x_{j}-\mu\right)}{\sum_{i}\left(x_{i}-\mu\right)^{2}} ; \\
I_{L i}=N \cdot \frac{\left(x_{i}-\mu\right) \sum_{i} w_{i j}\left(x_{j}-\mu\right)}{\sum_{i}\left(x_{i}-\mu\right)^{2}},
\end{gathered}
$$

where $I_{G}$ is the global autocorrelation index of the given regions; $I_{L i}$ is the local autocorrelation index of the given regions; $N$ is the number of regions; $W_{i j}$ is the element of the matrix of spatial weights

\begin{tabular}{|c|c|}
\hline $\begin{array}{l}\text { Study of the structure } \\
\text { of research talent } \\
\text { (methods of multiple } \\
\text { regression analysis) }\end{array}$ & $\begin{array}{l}\text { 1 - Correlation analysis; } \\
\text { '• Regression modeling of the structure of research talent, the search for its basic } \\
\text { I elements; } \\
\text { • Assessment of the model's reliability }\end{array}$ \\
\hline$\downarrow$ & $\begin{array}{l}\text { Construction of a standardized distance matrix (along linear distances, along } \\
\text { roads between administrative centers of Russian regions, as well as along }\end{array}$ \\
\hline $\begin{array}{l}\text { Spatial autocorrelation } \\
\text { of Russian regions in terms } \\
\text { of the development } \\
\text { of elements of research talent }\end{array}$ & $\begin{array}{l}\text { adjacent borders between Russian regions); } \\
\text { - Calculation of the global autocorrelation index of the } r \\
\text { ment of the basic elements of research talent using the }\end{array}$ \\
\hline$\Delta$ & $\begin{array}{l}\text { (clustering and identification of the main categories of regions by categories } \\
\text { HH, HL, LL, LH); }\end{array}$ \\
\hline $\begin{array}{l}\text { Formation of a spatial } \\
\text { autoregressive model } \\
\text { of regional interaction } \\
\text { in the development } \\
\text { processes of the basic } \\
\text { elements of research talent }\end{array}$ & $\begin{array}{l}\text { - Search for interconnected regions by the matrix of local autocorrelation indices; } \\
\text { - Verification of the revealed interregional interconnections in the development } \\
\text { processes of the basic elements of research talent by applying the method of } \\
\text { correlation analysis using time series; } \\
\text { - Cartographic display of the dispersion diagram of P. Moran with identified } \\
\text { interregional relationships using network lines. }\end{array}$ \\
\hline
\end{tabular}
for regions $i$ and $j ; \mu$ is the average value of the in-

Figure 2. Algorithm for the study of interregional relationships in the development of research talent Source: compiled by the authors by using the data from [38] 
dicator; $x_{i}$ is the analyzed indicator of one region; $x_{j}$ is the analyzed indicator of another region.

We propose to conduct the analysis the spatial relationship between regions for the development of the basic elements of research talent by forming a dispersal diagram of P. Moran (Figure 3). This diagram will allow us to group the regions into four categories (HH, HL, LL, LH) depending on the level of development of human resources and the features of their spatial distribution. In contrast to the traditional approach, in this study in each category of regions we propose to distinguish territories with high values of the local autocorrelation index (above the average value). This will allow us to select territories with the highest degree of interconnection and cluster them out of the totality of regional systems belonging to a particular category (HH, HL, LL, LH). This refinement of the traditional methodological approach is explained by the need to eliminate the ambiguity of the results.

\begin{tabular}{|c|c|}
\hline \multicolumn{2}{|c|}{$\boldsymbol{W}$} \\
\hline $\begin{array}{l}\text { Category LH: } \\
\text { territories with negative } \\
\text { autocorrelation, having } \\
\text { relatively low values of the } \\
\text { analyzed indicator, are } \\
\text { surrounded by territories with } \\
\text { relatively high values of the } \\
\text { analyzed indicator. These } \\
\text { territories are a zone of } \\
\text { influence of territories located } \\
\text { in the quadrants } \mathrm{HL} \text { and } \mathrm{HH}\end{array}$ & $\begin{array}{l}\text { Category HH: } \\
\text { territories with positive } \\
\text { autocorrelation, having high } \\
\text { values of the analyzed indicator } \\
\text { and surrounded by territories } \\
\text { with high values of this indicator. } \\
\text { These territories cannot become } \\
\text { growth poles, as they have high } \\
\text { values of the indicator. These are } \\
\text { satellite territories, } \\
\text { (counterweights to the core) }\end{array}$ \\
\hline $\begin{array}{l}\text { LL Category: } \\
\text { territories with positive } \\
\text { autocorrelation, having } \\
\text { relatively low values of the } \\
\text { analyzed indicator, surrounded } \\
\text { by territories with low values of } \\
\text { the analyzed indicator. These } \\
\text { territories are not connected } \\
\text { with others and are not affected } \\
\text { by either cores or } \\
\text { counterbalancing satellites. }\end{array}$ & $\begin{array}{c}\text { Category HL: } \\
\text { territories with negative } \\
\text { autocorrelation, having a high } \\
\text { value of the analyzed indicator, } \\
\text { surrounded by territories with } \\
\text { relatively low values of the } \\
\text { analyzed indicator. These } \\
\text { territories are growth poles } \\
\text { (cores), zones of high } \\
\text { concentration of the studied } \\
\text { resources }\end{array}$ \\
\hline
\end{tabular}

Figure 3. Patrick Moran P. Dispersion Diagram Source: compiled by the authors by using the data from [38]

According to the Moran P. dispersion diagram, the HL category includes regions with a high value of the analyzed indicator and surrounded by territories with relatively low values of this indicator. These territories are the 'growth poles' for other territorial systems. However, calculations of the local Moran autocorrelation indices show that regions with weak interregional relationships, which are not growth poles, can also be included in this category. Regional systems located in the $\mathrm{HH}$ and $\mathrm{LH}$ categories are a kind of zone of mutual influence of the 'growth poles' and have a close relationship with them. At the same time, not all regions of these categories have high values of local autocorrelation indices. As a result, a contradictory situation arises, according to which the relationship between the regions revealed in the P. Moran Dispersion Diagram is not confirmed by calculations of autocorrelation indices. Therefore, to the truly interconnected regional systems in the $\mathrm{HH}$ and $\mathrm{LH}$ categories, we propose to assign only territories with high autocorrelation indices (if they exceed the average value calculated for all Russian regions). The remaining regions in the $\mathrm{HH}$ and $\mathrm{LH}$ categories are not associated with HL, but receive impetus from their development. The development of the traditional methodological approach to spatial autocorrelation was carried out in the direction of confirming the identified relationships between territorial systems. The revealed interregional relationships in terms of the development of research talent as a result of the formation of a matrix of values of local autocorrelation indices, we propose to check using correlation analysis using time series. Correlation analysis will allow us to assess the tightness of the revealed relationship between the regions not only by spatial but also by temporary statistics.

The established interconnections between the regions in the processes of developing research talent are presented for illustrative purposes in cartograms. Its basis will be formed by the results of the clustering of territories according to the dispersion diagram of P. Moran, as well as interregional relationships established by the matrix of local autocorrelation indices. We propose to depict the relationships between the regions in the cartogram in the form of network lines. The final stage in the study of interregional ties in the development of research talent is the formation of a spatial autoregressive model of the interconnection of regions. This stage not only confirms the relationships between the regions identified at the previous stage, but also forms a model that predicts a change in these relationships in the future.

\section{Results and discussion}

In this study, we propose to consider research talent from the perspective of resources (as intellectual resources of a particular territory) and from the perspective of ability of a certain territorial system to form and develop an innovative economy. Human resources are drivers of innovative economy. In our opinion, territorial systems 
can engage in active innovative development even if their research talent is insufficient through interregional ties and cooperation with other territories with stronger scientific potential. The study of such interregional relations will allow us to draw conclusions about the readiness of regional systems for innovative development.

In accordance with the resource-related approach, the research talent in regions comprises researchers (specialists in STEM fields); engineering and technical staff; and support staff.

We used the statistical data for 82 Russian regions for 2017 to conduct multiple least squares regression analysis and identified the two main elements of the research talent structure necessary for the formation and development of an innovative economy:

$$
R T=1.64 R+1.73 E S,
$$

where $R T$ is research talent (the number of employees engaged in $R \& D$ ), people; $R$ is the number of researchers, people; $E S$ is the number of engineering staff, people.

The regression analysis did not include statistics on the Jewish Autonomous Region and the Chukotka Autonomous Region due to the lack of data; Tyumen Region was considered without the Yamalo-Nenets and Khanty-Mansiysk Autonomous Districts to avoid double counting. The constructed regression model satisfies all the necessary requirements: the initial data have a normal Gaussian distribution, there are enough observations to conduct the study, the main regression parameters are statistically significant. There is no multicollinearity between factor signs and autocorrelation between residues in the model. The reliability of the regression model was confirmed by graphical analysis. The curves of the real and simulated values of the number of staff engaged in $\mathrm{R} \& \mathrm{D}$ coincided completely. There were no significant deviations from the constructed model (see Table 2).

The results of the regression model based on the spatial data are shown in Table 1 above. They allowed us to conclude that the formation of an innovative economy requires the reproduction of R\&D personnel. The second spatial regression model revealed those elements of research talent that should be prioritized in talent development. In the course of the study, we came to the conclusion that for innovative development of regional systems, it is essential to put the main emphasis on the development of the research talent in the STEM fields. Unfortunately, the number of such specialists has fallen sharply in the recent years (Figure 4): from 2000 to 2017, the number of research staff decreased by $20 \%$ (179,842 people).

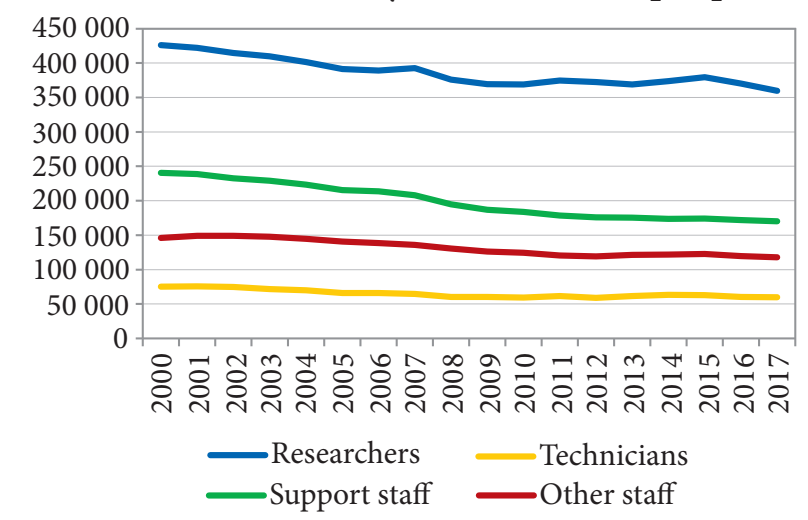

Figure 4. Dynamics of research talent in Russia in 2010-2017, people

Source: the authors' calculations are based on the data from 'Regions of Russia. Socio-economic indicators'. 2018, statistical data. Moscow: Rosstat; 2018, pp. 1162, 902-907

Table 2

\section{Results of spatial regression analysis of research talent in Russian regions in 2017}

\begin{tabular}{lr}
\hline Regression statistics & \\
\hline Correlation coefficient $(R)$ & 1.00 \\
Coefficient of determination & 1.00 \\
Standard error & 1545 \\
\hline
\end{tabular}

Analysis of variance

\begin{tabular}{lrrrrr}
\hline & $\mathrm{d} f$ & \multicolumn{1}{c}{$S S$} & \multicolumn{1}{c}{ MS } & \multicolumn{1}{c}{$F$} & $F$ value \\
\hline Regression & 2 & $6.79 \mathrm{E}+10$ & $3.39 \mathrm{E}+10$ & 14212.0 & $9.7 \mathrm{E}-102$ \\
Residual & 80 & $1.91 \mathrm{E}+08$ & 2387957 & & \\
Total & 82 & $6.81 \mathrm{E}+10$ & & & \\
\hline
\end{tabular}

\begin{tabular}{lrrrrrr}
\hline Regression coefficients & & Standard error & \multicolumn{1}{c}{ t-statistics } & \multicolumn{1}{c}{$P$-value } & Lower 95\% & Upper 95\% \\
\hline$R$ & 1.64 & 0.08 & 20.21 & $3.6 \mathrm{E}-33$ & 1.48 & 1.80 \\
$E P$ & 1.73 & 0.52 & 3.31 & 0.001 & 0.69 & 2.78 \\
\hline
\end{tabular}

Source: the authors' calculations are based on the data from 'Regions of Russia. Socio-economic indicators'. 2018, statistical data. Moscow: Rosstat; 2018, pp. 1162, 902-907, 954-955. 
The number of researchers and engineers decreased by $15 \%$ and $20 \%$ respectively in the same period. Calculation of the global and local Moran indices by the number of R\&D personnel in Russian regions in 2017 allowed us to create a dispersion diagram of Moran P. and group the given regions into four categories (HH, HL, LL, LH). These categories were formed on the basis of the development indicator of research talent and the patterns of its spatial distribution (see Table 3 ).

The HL category included regions with negative autocorrelation and relatively high values of the number of R\&D personnel, namely, Tomsk and Novosibirsk regions. These regions are growth poles as they are surrounded by territories with a smaller number of researchers and engineers. On the other hand, these territories are spatially remote and, therefore, lack close interconnections with other regional systems (Figure 5).

The cartographic image of the Moran dispersion diagram shows that the eastern part of Russia (highlighted in white colour) was not interconnected with other regions in using research talent, even with those regions that are considered as 'growth poles'. The research talent of the innovation economies in Tomsk and Novosibirsk regions is sought only by the Khanty-Mansi Autonomous District, Yamalo-Nenets Autonomous District, Tyumen, Omsk, Kemerovo Regions, and Altai Krai. These regions are zones of influence of the specific growth pole, as they have less human resources in $\mathrm{R} \& \mathrm{D}$, a smaller number of researchers and engineers.

The category of regions with a high level of development of research talent (category $\mathrm{HH}$ ) and close interconnections with other territorial systems includes Moscow and Nizhny Novgorod regions, the city of Moscow and the city of St. Petersburg. In these regions, according to the calculation results presented in Table 3, a positive autocorrelation is observed, the local Moran index exceeds the country's average level (0.001). The increase in the number of R\&D personnel in these regions will contribute to its growth in other related territorial systems in the LH category.

Other territorial systems, such as Sverdlovsk, Chelyabinsk, Voronezh, Kaluga, Samara, Rostov regions, Tatarstan and Perm Krais are also included in the category of regions with a high level of development of research talent and innovative

Table 3

\section{Moran dispersion diagram of research talent development in Russian regions} with the values of the local autocorrelation index

\begin{tabular}{|c|c|c|c|}
\hline \multicolumn{2}{|l|}{ LH } & \multicolumn{2}{|l|}{ HH } \\
\hline Ryazan Region & -0.00272 & Moscow Region & 0.03055 \\
\hline Tver Region & -0.00151 & Moscow City & 0.02057 \\
\hline Ivanovo Region & -0.00148 & St. Petersburg City & 0.00442 \\
\hline Tula Region & -0.00148 & Nizhny Novgorod Region & 0.00415 \\
\hline Kostroma Region & -0.00122 & Kaluga Region & 0.00026 \\
\hline Novgorod Region & -0.00110 & Voronezh Region & 0.00013 \\
\hline \begin{tabular}{|l|l|} 
Vladimir Region & \\
\end{tabular} & -0.00102 & Republic of Tatarstan & 0.00010 \\
\hline \multirow{5}{*}{\multicolumn{2}{|c|}{$\begin{array}{l}\text { - Smolensk, Oryol, Lipetsk, Bryansk, Vologda, Tambov, Pskov, Leningrad, Kursk, } \\
\text { Yaroslavl, Belgorod, Arkhangelsk, Kaliningrad, Kirov, Penza, Murmansk, Oren- } \\
\text { burg, Ulyanovsk, Kurgan, Saratov, Omsk, Volgograd regions; } \\
\text { - Republics: Mordovia, Karelia, Chuvashia, Mari El, Udmurtia, Komi and Bashkor- } \\
\text { tostan; } \\
\text { - Altai Krai; } \\
\text { - Yamal-Nenets and Khanty-Mansi Autonomous Districts. }\end{array}$}} & Sverdlovsk Region & 0.00009 \\
\hline & & Chelyabinsk Region & 0.00007 \\
\hline & & Samara Region & 0.00005 \\
\hline & & Perm Krai & 0.00003 \\
\hline & & Rostov Region & 0.00000 \\
\hline \multicolumn{2}{|l|}{ LL } & \multicolumn{2}{|l|}{ HL } \\
\hline \multirow{2}{*}{\multicolumn{2}{|c|}{$\begin{array}{l}\text { - Amur, Magadan, Irkutsk, Sakhalin, Astrakhan regions; } \\
\text { - Republics: Ingushetia, North Ossetia-Alania, Dagestan, Crimea, Kalmykia, } \\
\text { Tuva, Adygea, Khakassia, Sakha (Yakutia), Buryatia, Altai, Chechen, Kab- } \\
\text { ardino-Balkaria, Karachaevo-Cherkessk; } \\
\text { - Stavropol, Khabarovsk, Transbaikal, Krasnodar, Primorsky, Krasnoyarsk, Kam- } \\
\text { chatka Krais; } \\
\text { - Chukotka Autonomous Region; } \\
\text { - Jewish Autonomous Region; } \\
\text { - Sevastopol City. }\end{array}$}} & Novosibirsk Region & -0.00028 \\
\hline & & Tomsk Region & -0.00004 \\
\hline
\end{tabular}




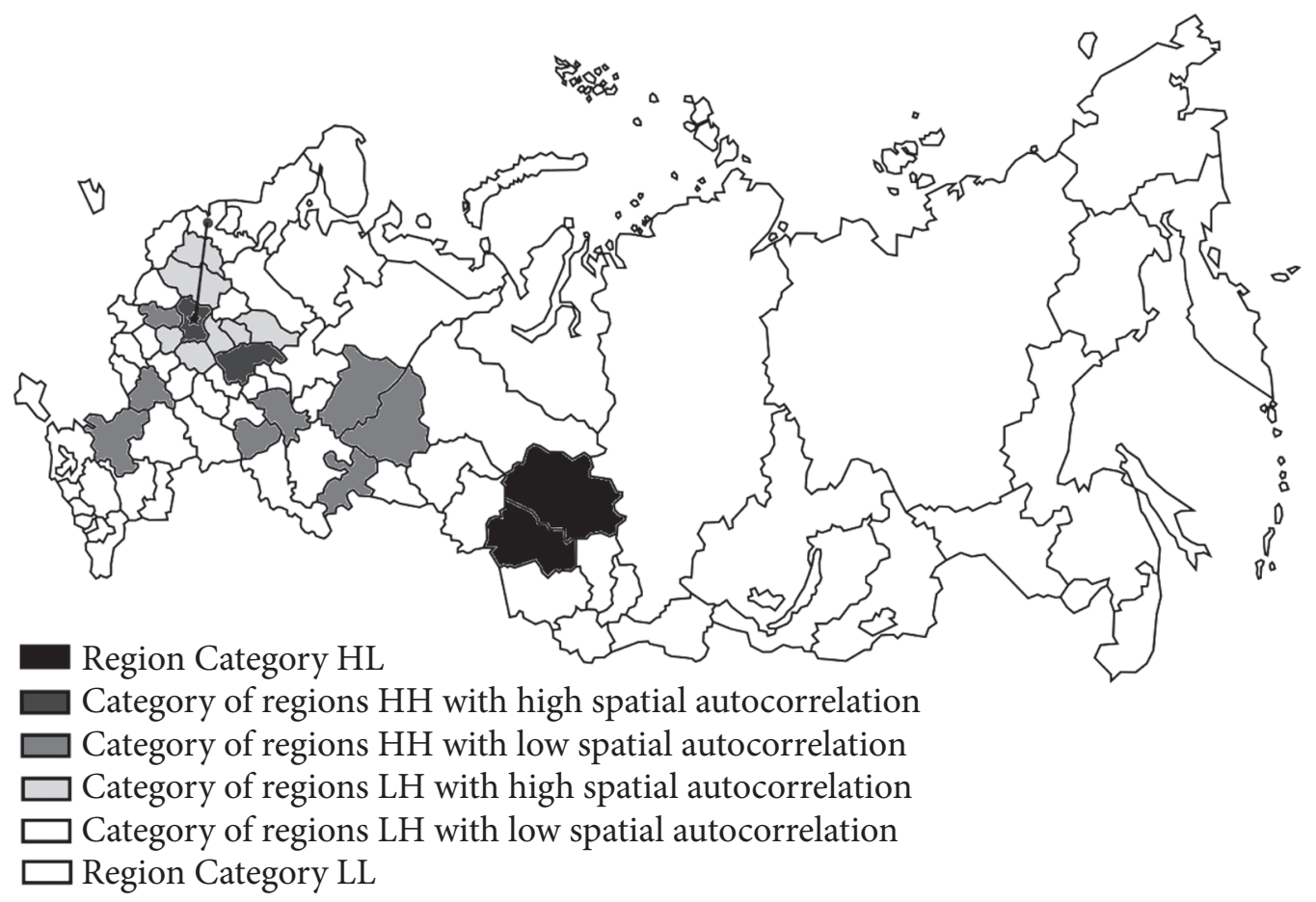

Figure 5. Cartographic image of the Moran dispersion diagram by the number of $R \& D$ personnel in Russian regions in 2017

Source: the authors' calculations are based on the data from 'Regions of Russia. Socio-economic indicators'. 2018, statistical data. Moscow: Rosstat; 2018, pp. 1162, 902-907

economy (HH category). These regions have powerful human resources in $\mathrm{R} \& \mathrm{D}$, however, unlike other territorial systems in this category, they do not have close interregional ties with other territories for its use. Their influence on the development of the human potential of the surrounding territories is not as strong as that of Moscow and Nizhny Novgorod regions, the city of Moscow and the city of St. Petersburg (see Figure 5, the surrounding areas are highlighted in grey colour). Regions with developed research talent and close interregional ties, in contrast, have a stronger influence on the adjacent territorial systems included in the LH quadrant. In Figure 5, the zone of strong influence is highlighted in darker gray and includes Ryazan, Tver, Ivanovo, Tula and Kostroma regions. These regions are closely connected with the city of Moscow and Moscow region and together form a cluster for the development of research talent. The formation of a matrix of local Moran autocorrelation indices confirmed the presence of close interregional relationships between these regions (see Table 4). The local Moran autocorrelation index for interregional relationships presented in Table 4 exceeds the average value calculated for all Russian regions (0.0011).
Table 4

The value of local autocorrelation and correlation indices by time series for the period 2000-2017 between closely interconnected regions for research talent

\begin{tabular}{|c|c|c|c|}
\hline $\begin{array}{l}\text { Region } \\
\text { included } \\
\text { in the HH } \\
\text { category } \\
\text { with strong } \\
\text { research } \\
\text { talent }\end{array}$ & $\begin{array}{l}\text { Regions included } \\
\text { in the LH category, } \\
\text { with less developed } \\
\text { research talent, but } \\
\text { included in the zone } \\
\text { of influence of the } \\
\text { HH category }\end{array}$ & $\begin{array}{l}\text { Local } \\
\text { Moran } \\
\text { Autocor- } \\
\text { relation } \\
\text { Index for } \\
2017\end{array}$ & $\begin{array}{l}\text { Cor- } \\
\text { relation } \\
\text { coefficient } \\
\text { between } \\
\text { regions } \\
\text { calculated } \\
\text { over time } \\
\text { series }\end{array}$ \\
\hline $\begin{array}{l}\text { St. Peters- } \\
\text { burg City }\end{array}$ & $\begin{array}{l}\text { Nizhny Novgorod } \\
\text { Region }\end{array}$ & 0.0029 & -0.31 \\
\hline \multirow{8}{*}{$\begin{array}{l}\text { Moscow } \\
\text { City }\end{array}$} & Saint Petersburg City & 0.0054 & 0.61 \\
\hline & Moscow Region & 0.0373 & -0.39 \\
\hline & $\begin{array}{l}\text { Nizhny Novgorod } \\
\text { Region }\end{array}$ & 0.0033 & -0.26 \\
\hline & Ryazan Oblast & -0.0017 & 0.08 \\
\hline & Ivanovo Region & -0.0015 & 0.51 \\
\hline & Tver Region & -0.0014 & 0.74 \\
\hline & Kostroma Region & -0.0014 & 0.25 \\
\hline & Tula Region & -0.0013 & 0.13 \\
\hline \multirow{3}{*}{$\begin{array}{l}\text { Moscow } \\
\text { Region }\end{array}$} & St.Petersburg City & 0.0017 & -0.50 \\
\hline & Ryazan Region & -0.0015 & 0.17 \\
\hline & $\begin{array}{l}\text { Nizhny Novgorod } \\
\text { Region }\end{array}$ & 0.0014 & -0.05 \\
\hline
\end{tabular}

Source: the authors' calculations are based on the data from 'Regions of Russia. Socio-economic indicators'. 2018, statistical data. Moscow: Rosstat; 2018, pp. 1162, 902-907. 
For other regions that are not represented in this table, the value of this indicator is significantly lower than the average. This once again confirms the presence of a not significant influence of regions with powerful scientific personnel potential (Sverdlovsk, Chelyabinsk, Voronezh, Kaluga, Samara, Rostov regions, Tatarstan and Perm Krai) on the territorial systems included in the LH category. The formation of a matrix of local autocorrelation indices made it possible to identify the direction of interregional interconnections (Table 4). Thus, we revealed a positive relationship between the city of St. Petersburg and Nizhny Novgorod Region, between the city of Moscow and the city of St. Petersburg, Moscow and Nizhny Novgorod regions as well as Moscow and Nizhny Novgorod regions, the city of St. Petersburg.

A positive autocorrelation relationship indicates a possible joint increase or decrease in the number of R\&D personnel in related regions. Accordingly, the development of the research talent in Moscow will contribute to its growth in St. Petersburg, Moscow and Nizhny Novgorod regions. The negative value of the local Moran index, on the contrary, characterizes multidirectional interconnections between regional systems (growth of the indicator in one region and its decrease in another). As a result, an increase in the number of R\&D personnel in the city of Moscow will affect its reduction in Ryazan, Ivanovo, Tver, Kostroma and Tula regions. Based on the identified relationships, we can conclude that the development of the research talent of the city of Moscow will occur primarily due to these regions.

Correlation analysis of interregional relationships in terms of the research talent development based on time series for the period 2000-2017 allowed us to identify the most stable relationships observed over a long period. An example of such a stable interregional relationship is the relationship between the city of Moscow and the city of St. Petersburg (the correlation coefficient was 0.61 ). In other cases, the calculated correlation coefficient was either significantly lower than the threshold value or the sign of the established relationship did not match the va-lue of the local Moran index. Thus, the study of interregional relationships using the improved spatial autocorrelation technique of P. Moran allowed us to establish a cluster of closely related regions (Moscow - St. Petersburg - Moscow Region - Nizhny Novgorod Region - Ryazan Re- gion - Ivanovo Region - Tver Region - Kostroma Region - Tula Region). We have identified three centers of potential clusters: Volga (Samara Region - Tatarstan), Ural (Sverdlovsk Region Chelyabinsk Region - Perm Krai), and Siberia (Tomsk Region - Novosibirsk Region).

Centers of potential clusters have significant human potential for development of an innovative economy but have not yet developed relationships with other regional systems. A zone of influence is formed in their environment, there are regions that need researchers in the field of basic, applied R\&D. These regions are also experiencing a shortage of engineering and technical personnel involved in setting up, adjusting, and checking the operational status of instruments and equipment involved in experiments, testing, software development and preparation of technical documentation.

For the formation and development of an innovative economy in Russia, we consider it necessary not only to strengthen the already existing cooperative ties in central regions, but also to establish them in the Ural, Volga and Siberian macroregions.

\section{Conclusion}

Our study showed that not all territorial systems possess the scientific and technical potential necessary for the formation of an innovative economy, innovative infrastructure and training highly qualified research staff. This situation seriously complicates the process of innovative development of these territories, but does not impede its implementation. In the modern conditions of economic development and increasing cooperation between territorial systems, generation and implementation of technological innovation does not require each region to build new research institutions and a powerful innovation infrastructure. Instead, it is necessary to establish and maintain close relationships with the research facilities operating in other territorial systems, objects of innovative infrastructure that have strong research talent. Territorial cooperation can involve exchange of experience in the sphere of development and implementation of technologies, training of research and engineering personnel, maintenance of innovative production technologies and so on. Such interregional cooperation will, in our opinion, enable Russian regions mutually enhance their innovative development. 


\section{References}

1. Naumov, I.V. (2015). Reproduction of Research and Engineering-Technical Personnel as the Leading Factor of Innovation in Russia. Izvestiya Uralskogo gosudarstvennogo ekonomicheskogo universiteta = Journal of the Ural State University of Economics, 1, 71-78. (In Russ.) Retrieved from: http://jne.usue.ru/en/-2015/377.

2. Naumov, I.V. (2011). Features of scenario planning of the innovative development of the territorial system. Zhurnal ekonomicheskoi teorii = Russian Journal of Economic Theory, 1, 81-95. (In Russ.)

3. Becker, G. (2003) Human behavior: an economic approach. Moscow: Higher School of Economics. (In Russ.)

4. Tatarkin, A.I. (2011) Intellectual resource of society. Vestnik rossijskoj akademii nauk, 81(8), 684. (In Russ.) Retrieved from: http://naukarus.com/intellektualnyy-resurs-obschestva.

5. Aquinas, T. (ed.) (2002). Summa Theologica. Kiev: Elga, Nika-Center, El-Cor-MK, Bookplate. (In Russ.)

6. Subetto, A.I. (1999) Russia and humanity on the 'pass' of history on the eve of the third millennium. St. Petersburg: PANIL. (In Russ.)

7. Kleiner, G.B., Tambovtsev V.A., \& Kachalov R.M. (1997). An enterprise in an unstable economic environment: risks, economic strategies, security. Moscow: Economics. (In Russ.) Retrieved from: http://ecsocman.hse.ru/text/19161564/.

8. Lezhnina, Yu.P. (2006). The relationship of socio-economic indicators of the region with the intellectual potential of its population. Transactions of the Siberian State University, 99, 22-33. (In Russ.)

9. Martynov, A.F. (2008). Reproduction of intellectual potential: assessment, modeling, management methodology: dissertation abstract of Doctor of Economics. Moscow. (In Russ.) Retrieved from: http://dissers.ru/avtoreferati-dissertatsii-ekonomika/a1029.php.

10. Grinin L.E., \& Korotaev A.V. (Eds) (2018). Kondratieff waves: to the $125^{\text {th }}$ birthday of N.D. Kondratyev. Volgograd: Uchitel. (In Russ.)

11. Sokhan L.V., \& Sokhan A.V. (1983). The intellectual potential of the individual. In The social structure of a socialist society (pp. 150-166). Moscow: Nauka. (In Russ.)

12. Chardin, P.T. (1987). The phenomenon of man. Moscow: Progress. (In Russ.)

13. Ovsyannikov, A.A. (2011) Potential for modernisation of the Russian higher school: competences communication of the professorate and students. Population, 4, 76-96. (In Russ.)

14. Leonidova, G.V. (2014). Intellectual potential of population: theoretical and methodological framework for research. Economic and Social Changes: Facts, Trends, Forecast, 1, 43-58. doi: 10.15838/esc/2014.1.31.6.

15. Kudina, M.V. (2010). Management of the Company's Intellectual Potential as an Element of the Corporate Governance. Gosudarstvennoe upravlenie. Elektronnyi vestnik $=$ E-Journal Public Administration, 22. (In Russ.) Retrieved from: http://ee-journal.spa.msu.ru/vestnik/item/22_2010kudina.htm.

16. Lagutina, L.G. (2009) Management of the region's intellectual potential in the context of an emerging innovative economy: macroeconomic aspect: dissertation abstract of Candidate of Economic Sciences. Moscow. (In Russ.) Retrieved from: https://www.dissercat.com/content/upravlenie-intellektualnym-potentsialom-regiona-v-usloviyakh-formiruyushcheisya-innovatsionn.

17. Makrusev, V.V., \& Spiders A.A. (2005). The system of cross-border protection of intellectual property. Moscow: RTA. (In Russ.)

18. Golovach, L.G., Krayukhin, G.A., \& Shaibakova, L.F. (1997). Regulation of innovative processes in the region. St. Petersburg: St. Petersburg State Academy of Engineering and Economics. (In Russ.)

19. Marusinina, E.Yu. (2007). Managing the intellectual resources of an enterprise within the framework of implementing the concept of intra-organizational marketing. dissertation abstract of Candidate of Economic Sciences. Volgograd. (In Russ.) Retrieved from: https://new-disser.ru/_avtoreferats/01003370133.pdf.

20. Demortain, D. (2017). Expertise, regulatory science and the evaluation of technology and risk. Introduction to the special issue. Minerva, 55, 139-159. doi: 10.1007/s11024-017-9325-1. 
21. Ghazinoory, S., Farazkish, M., Montazer, G.A., \& Soltani, B. (2017). Designing a national science and technology evaluation system based on a new typology of international practices. Technological Forecasting and Social Change, 122, 119-127. doi: 10.1016/j.techfore.2017.04.012.

22. Wang, D., Song, C., \& Barabasi, A.-L. (2013). Quantifying long-term scientific impact. Science, 342(6154), 127-132. doi: 10.1126/science.1237825.

23. Serrano-Pozo, A., Aldridge, G.M., \& Zhang, Q. (2017) Four decades of research in Alzheimer's Disease (1975-2014): A Bibliometric and scientometric analysis. Journal of Alzheimers Disease, 59(2), 763-783. doi: 10.3233/JAD-170184.

24. Chenlei, M., \& Jianfeng, H. (2019) Study of Practices and Innovation of the Applied Personnel Training Model at Private Institutions of Higher Education. Chinese Education \& Society, 52(1-2), 90-98.

25. Tyler, K. (2019). Bright ideas. HR Magazine, 64(1), 46-51.

26. Turkulainen, V.; \& Swink, M.L. (2017). Supply Chain Personnel as Knowledge Resources for Innovation-A Contingency View. Journal of Supply Chain Management, 53(3), 41-59. doi: 10.1111/ jscm.12133.

27. Li, Y., Wang, M., Danielle D., Lee, G.K., \& Ma, D.G. (2018). From Employee-Experienced High-Involvement Work System to Innovation: An Emergence-Based Human Resource Management Framework. Academy of Management Journal, 61(5). doi: 10.5465/amj.2015.1101.

28. Safonov, Yu.M., Maslennikov, E.I., \& Borshch, V.I. (2018). Innovation training and development technologies for managerial personnel. Scientific Bulletin of Polissia, 2-2, 154-159. doi: 10.25140/2410-9576-2018-2-2(14)-154-159.

29. Agnihotri, R., Yang, Zh., \& Briggs, E. (2019). Salesperson time perspectives and customer willingness to pay more: roles of intraorganizational employee navigation, customer satisfaction, and firm innovation climate. Journal of Personal Selling \& Sales Management, 39(2), 138-158. doi: 10.1080/08853134.2018.1562352.

30. Teddy Lian Kok Fei, \& Law Kian Aun (2019). The Impact of Human Resource Management Bundles on Innovation in Malaysia. Journal of Applied Economics \& Business Research, 9(1), 83-95.

31. Yang J. Research on the innovation method of continuing education model for professional technical personnel in manufacturing industry (2018). Educational Sciences: Theory \& Practice. 18(5), 2325-2331. doi: 10.12738/estp.2018.5.130.

32. Liu, D., Gong, Y., Zhou, J., \& Huang, J.-C. (2017). Human resource systems, employee creativity, and firm innovation: the moderating role of firm ownership. Academy of Management Journal, 60(3), 1164-1188. doi: 10.5465/amj.2015.0230.

33. Alonso, W. (1964). Location and Land Use. Cambridge, MA: Harvard University Press.

34. Moran, P. (1948). The interpretation of statistical maps. Journal of the Royal Statistical Society, Series B, 10, 243-251.

35. Anselin, L. (1988). Spatial Econometrics: Methods and Models. Dordrecht: Kluwer Academic Publishers. doi: 10.1007/978-94-015-7799-1.

36. Geary, R. (1954) The contiguity ratio and statistical mapping. The Incorporated Statistician, 5(3), 115-145. doi: 10.2307/2986645.

37. Getis, A.; \& Ord, J.K. (1996). Local Spatial Statistics: An Overview. In Longley, P., Batty, M., (Eds). Spatial Analysis: Modeling in a GIS Environment. Cambridge, UK: John Wiley \& Sons.

38. Naumov, I.V. (2019). Investigation of the Interregional Relationships in the Processes of Shaping the Territories' Investment Potential Using the Methods of Spatial Modelling. Ekonomika regiona $=$ Regional Economy, 15(3), 720-735. doi: 10.17059/2019-3-8.

\section{Information about the authors}

Ilya V. Naumov - Cand. Sc. (Economics), Head of the Laboratory for Spatial Development of Territories, Institute of Economics, Ural Branch of the Russian Academy of Sciences (29 Moskovskaya Str., 620014, Ekaterinburg, Russia); Associate Professor, Ural State Mining University (30 Kuibysheva Str., 620144, Ekaterinburg, Russia); Associate Professor, Ural State Economic University (62/45 Str. 8 Marta/Narodnoy voli, 620144, Ekaterinburg, Russia); e-mail: Ilia_naumov@list.ru 
Anna Z. Barybina - Junior Researcher, Laboratory for Spatial Development of Territories, Institute of Economics, Ural Branch of the Russian Academy of Sciences (29 Moskovskaya Str., 620014, Ekaterinburg, Russia) ; e-mail: ag-91@mail.ru

ARTICLE INFO: received November 12, 2019; accepted February 20, 2020

\section{Информация об авторах}

Наумов Илья Викторович - кандидат экономических наук, заведующий лабораторией пространственного развития территорий, Институт экономики Уральского отделения Российской академии наук (620014, Россия, г. Екатеринбург, ул. Московская, 29); доцент, Уральский государственный горный университет (620144, Россия, г. Екатеринбург, ул. Куйбышева, 30); доцент, Уральский государственный экономический университет (620144, Россия, Екатеринбург, ул. 8 марта/Народной воли, 62/45); e-mail: Ilia_naumov@list.ru

Барыбина Анна Зинуровна - младший научный сотрудник, лаборатория пространственного развития территорий, Институт экономики Уральского отделения Российской академии наук (620014, Россия, г. Екатеринбург, ул. Московская, 29); e-mail: ag-91@mail.ru

ИНФОРМАЦИЯ О СТАТЬЕ: дата поступления 12 ноября 2019 г.; дата принятия к печати 20 февраля 2020 г. 